\title{
Jual Beli Ampas Tahu Untuk Pakan Ternak Babi Di Pabrik Tahu Telaga Meuku Dua Tinjauan Sadd Adz-Dzariah
}

Reza Syahputra

Awwaluz Zikri

Muhammad Firdaus

\begin{abstract}
Abstrak
Penelitian ini bertujuan untuk mengkaji tinjauan sadd Adz-Dzariah teehadap jual beli ampas tahu untuk pakan ternak babi. Penelitian ini merupakan penelitian field research (penelitian lapangan) yang menggunakan pendekatan normatif-kualitatif, Penelitian ini dilakukan di Desa Telaga Meuku Dua Kecamatan Banda Mulia Kabupaten Aceh Tamiang, Dalam penelitian ini, analisis data dimulai dengan mengumpulkan seluruh data yang didapatkan dari proses wawancara observasi dan sumber-sumber lainnya. Kemudian data yang terkumpul dipelajari dan dipahami Apakah sudah sesuai dengan yang diharapkan. Setelah data dipelajari maka membuat Uraian singkat dan menghubungkannya dengan menggunakan teori-teori yang akan dipaparkan di bab selanjutnya. Yang telah disusun dibandingkan antara satu dengan lain, kemudian dibuat kesimpulan yang merupakan tahap akhir dalam analisis data mengenai jual beli ampas tahu untuk pakan ternak babi di pabrik tahu Telaga Meuku Dua tinjauan Sadd Adzdzari'ah. Hasil penelitian diperoleh bahwa Jual beli ampas tahu untuk pakan ternak babi di pabrik tahu desa Telaga Meuku Dua termasuk kategori jual beli yang dilarang. Dikarenakan dalam pemanfaatan ampas tahunya dijadikan sebagai pakan ternak babi. Agama Islam telah secara tegas melarang untuk memanfaatkan daging babi. Dengan
\end{abstract}


demikian dalam hukum Islam perbuatan jual beli ampas tahu untuk pakan ternak babi juga dilarang karena termasuk Sadd adz-Dzari'ah yang menutup jalan terjadinya kemafsadatan dalam jual beli ampas tahu untuk pakan ternak babi tergolong persangkaan yang kuat yang menyebabkan terjadinya hal-hal yang rusak dan dilarang. Jual beli ampas tahu untuk pakan ternak babi .

Kata Kunci: Sadd Adz-Dzari'ah, Jual Beli Terlarang, Hukum Ekonomi Syariah

\section{Pendahuluan}

Manusia diciptakan Allah SWT sebagai makhluk sosialdan mereka dijadikan saling berhajat kepada yang lain, supaya mereka saling tolong-menolong, tukar- menukar dalam segala urusan kepentingan hidup masing-masing, baik dengan jalan jual beli,sewamenyewa, bercocok tanam ataupun yang lain, baik dalam urusan diri sendirimaupun untuk kemaslahatan umum. ${ }^{1}$ Salah satu kegiatan ekonomi dalam Islam adalah jual beli.Kegiatan jual beli merupakansuatu pekerjaan yang baik, berdasarkan hadis Rasullullah SAW sebagaimana diriwayatkan oleh Rifa'ah ibn Rafi':

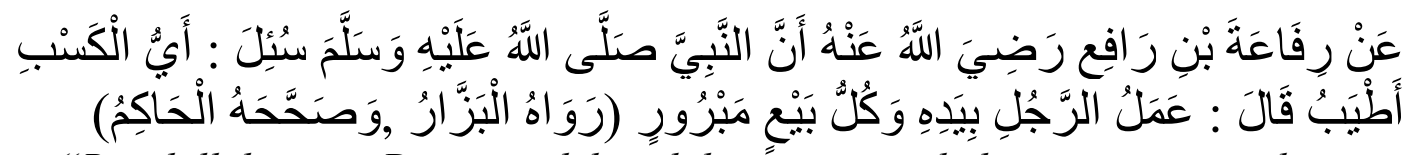

Artinya:"Rasulullah saw. Ditanya oleh salah séorang sahabat mengenai pekerjaan (Profesi) apa yang paling baik. Rasulullah saw. Menjawab: usaha tangan manusia sendiri dan setiap jual beli yang diberkati” (HR. Al-Bazzar dan AlHakim). ${ }^{2}$

${ }^{1}$ Sulaiman Rasjid, Fiqih Islam, (Jakarta: At-Tahiriyah, Cet. ke-17, 1954), h. 268.

${ }^{2} \mathrm{Al}-\mathrm{Hafiz}$ ibnu hazar al-'asqalani, terjemahan lengkap Bulughul Maram kumpuln hadis tentang hukum dan adab,(surakarta:Ziyad Books, 2017),h.274. 
Hadis diatas menjelaskan bahwa pekerjaan yang paling baik itu ialah pekerjaan yang kita kerjakan dengan usaha tangan kita sendiri dan jual beli yang diberkati.

Dikarenakan jual beli ini sesuatu yang baik tentunya ada aturan-aturan yang harus dipenuh dalam jual beli. Alquran dan hadis telah memberikan batasan-batasan yang jelas mengenai ruang lingkup jual beli tersebut, khususnya yang berkaitandengan 
hal-hal yang diperbolehkan dan yang dilarang. Sebagaimana firman Allah dalam surat Al-Baqarah ayat 275:

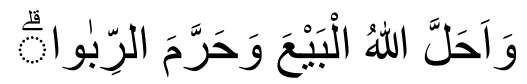

Artinya: "Dan Allah telah menghalalkan jual beli dan mengharamkan riba". (QS. Al-Baqarah: 275). ${ }^{3}$

Jual beli dapat dikategorikan sah jika telah memenuhi syarat dan rukunnya. Adapun rukun dalam jual beli menurut jumhur ulama ada empat, yaitu penjual,pembeli, sighat dan ma'qud alaih (objek akad). ${ }^{4}$ Sedangkan syarat jual beli menurut jumhur ulama ada empat garis besar yaitu syarat-syarat orang yang berakad, syarat-syarat terkait ijab dankabul, syarat-syarat barang yang diperjual belikan dan syarat-syarat nilai tukar. ${ }^{5}$

Berkaitan dengan barang yang diperjual belikan maka harus memenuhi persyaratan yaitu: barang-barang suci, bisa dimanfaatkan, milik orang yang melakukan akad, mampu menyerahkannya, mengetahui, dan barang yang diakadkan ada di tangan. Yang dimaksud dengan barang tersebut harus suci adalah bahwa barang yang diperjualbelikan bukanlah benda yang dikualifikasikan sebagai benda najis atau digolongkan sebagai benda yang diharamkan seperti arak, bangkai, anjing, babi dan berhala. ${ }^{6}$

Merujuk Hadis Nabi Muhammad SAW sebagaimana di riwayakan oleh Jabir:

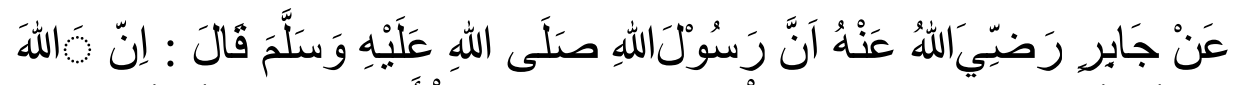

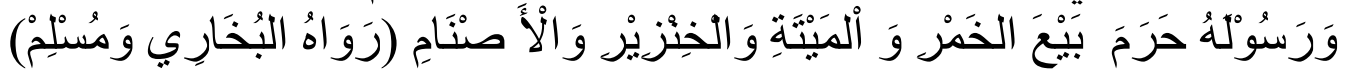
Artinya: "Dari Jabir,bahwa ia pernah mendengar nabi SAW berkata: sesungguhnya Allah dan Rasul-Nya telah mengharamkan menjual arak

\footnotetext{
${ }^{3}$ Departemen Agama, Al-Qur'an dan Terjemahnya, (Bandung: CV. Diponegoro, 2005), h.. 47.

${ }^{4}$ Ahmad Wardi Muslich, Fiqh Muamalat, (Jakarta: AMZAH, 2015), h. 180.

${ }^{5}$ Abdul Rahman Ghazaly, dkk., Fiqh Muamalat, (Jakarta: Kencena Prenada Media Group: 2010), h. 80-87.

${ }^{6}$ Moh. Rifa'i, Terjemah Khulasah Kifayatul Akhyar, (Semarang: PT. Toha Putra, 2005), h. 184.
} 
dan bangkai begitu juga dengan babi dan berhala" (HR. Bukhori Muslim). ${ }^{7}$

Dari hadis diatas telah jelas disebutkan tentang larangan jual beli arak dan bangkai serta jual beli babi dan berhala. Larangan terhadap bangkai, khamar dan babi di sebabkan karena ketiga objek tersebut termasuk barang najis yang haram dalam Islam sedangakan berhala di sebabkan merupakan sembahan orang yahudi

Mazhab Hanafi dan Zhahiri mengecualikan barang yang memiliki manfaat dan halal untuk diperjualbelikan. Mereka berpendapat bahwa dibolehkan menjual kotoran dan sampah-sampah yang mengandung najis, karena barang tersebut sangat dibutuhkan untuk keperluan pertanian, pupuk tanaman, dan bahan bakar tungku api. Demikian pula, boleh menjual barang-barang najis yang dapat dimanfaatkan bukan untuk dimakan dan diminum seperti, minyak najis yang digunakan sebagai bahan bakar dan cat pelapis.Semuabarang sejenis tersebut boleh diperjualbelikan selagi ada manfaatnya dan bukan untuk dimakan dan diminum, walaupun barang tersebut najis. $^{8}$

Dalam kaidah fiqih tentang muamalah di jelaskan bahwa:

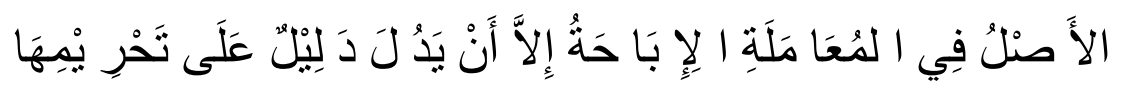

Artinya : Hukum asal semua bentukmuamalah adalah boleh dilakukan kecuali ada dalil yangmengharamkannya. ${ }^{9}$

\footnotetext{
${ }^{7}$ Asy-Syekh Faishal bin Abdul Azis Al-Mubarak,Terj.Nailul Authar, Himpunan Hadis-Hadis Hukum(Surabaya: PT. Bina Ilmu, 2009), h.1629.

${ }^{8}$ Sayyid Sabiq, Fiqih Sunnah,Jilid 5,Terj. Abu Syauqina Dan Abu Aulia Rahma(Jakarta: Tinta Abadi Gemilang,2013 ), h.51.

${ }^{9}$ Djazuli, Kaidah-Kaidah Fiqih: Kaidah-Kaidah Hukum Islam dalam Menyelesaikan Masalah-Masalah yang Praktis, (Jakarta: Kencana, 2006). h. 130.cs
} 
Maksud dari kaidah ini adalah setiap kegiatanmuamalah adalah boleh atau mubah, seperti jual beli, sewa-menyewa,gadai, dan lain sebagainya, kecuali yang secara tegas dilarang olehagama Islam seperti yang mengakibatkan kemudharatan, gharar, judi,dan riba. ${ }^{10}$

Di pabrik tahu Desa Telaga Meuku Dua Kecamatan Banda Mulia Kabupaten Aceh Tamiang terjadi jual beli tahu dan ampas tahu. Dalam hal ini pabrik tahu menyuplai kebutuhan tahu bagi masyarakat sekitarnya. Meningkatnya tingkat konsumsi tahu oleh masyarakat mendorong para produsen tahu meningkatkan produksi tahunya. Dengan demikian ampas tahu yang dihasilkan pun bertambah. Ampas tahu ini kemudian dijual kepada para pembeli yang memanfaatkannya sebagai pakan kambing,lembu bahkan ternak babi yang mana pembelinya datang dari luar daerah untuk membeli ampas tahu tersebut agar ternak mereka terpenuhi kebutuhan pakanya. Dari transaksi jual beli tersebut menimbulkan hubungan yang saling menguntungkan.Dari sisi penjual ampas tahu, dia mendapatkan tambahan penghasilan hasil penjualan ampas tahu tersebut sedangkan dari sisi pembeli mereka juga tenang dan legah karena persediaan pakan ternaknya terpenuhi. ${ }^{11}$

Merujuk pada transakasi jual beli diatas, penulis menemukan permasalahan yaitu bagaimana hukum menjual suatu barang yang suci yaitu ampas tahu yang digunakan untuk pakan ternak babi. Transaksi ini berarti secara tidak langsung penjual ampas tahu ikut membantu melancarkan usaha peternakan babi dengan cara menjual ampas tahu kepada mereka yang dimanfaatkan untuk memenuhi pakan

\footnotetext{
10 Djazuli, Kaidah-Kaidah Fiqih: Kaidah-Kaidah Hukum Islam dalam MenyelesaikanMasalah-Masalah yang Praktis, (Jakarta: Kencana, 2006), h. 128.

${ }^{11}$ Hasil observasi dan wawancara peneliti di pabrik tahu Desa Telaga Meuku Dua. Tanggal 12 Januari 2020
} 
ternak babinya. Padahal agama Islam secara tegas melarang mengkonsumsi babi termasuk di dalamnya adalah melakukan peternakan dan jual beli babi.

Adanya larangan jual beli babi dalam Islam dimaksudkan untuk melindungi masyarakat dari efek negatif jika mengkonsumsinya, karena babi mengandung cacing pita yang sangat berbahaya bagi manusia. ${ }^{12}$ Serta bagaimana jika ditinjau dari Sadd Adz-dzari'ah yang bertujuan untuk menetapkan hukum larangan atas suatu perbuatan tertentu yang pada dasarnya diperbolehkan maupun dilarang untuk mencegah terjadinya perbuatan lain yang dilarang.

Jual beli yang dilarang terbagi dari dua yaitu : pertama, jual beli yang dilarang dan hukumnya tidak sah(batal), ialah jual beli yang tidak memenuhi syarat dan rukun, kedua, jual beli yang hukumnya sah tetapi dilarang, yaitu jual beli yang telah memenuhi syaratdan rukunnya, tetapi ada beberapa faktor yang menghalang kebolehan proses jual beli.

a. Jual beli terlarang karena tidak memenuhi syarat dan rukun.

Bentuk jual beli yang termasuk dalam kategori ini sebagai berikut:

1) Jual beli barang yang zatnya haram, najis, atau tidak boleh diperjualbelikan. Adapun bentuk jual beli yang dilarang karena barangnya yang tidak boleh diperjualbelikan yaitu air susu ibu dan air mani (sperma) binatang. ${ }^{13}$

2) jual beli yang dilarang karena mengandung unsur gharar (belum jelas/samar-samar) antara lain:

\footnotetext{
${ }^{12}$ Yusuf Qardhawi, Halal dan Haram dalam Islam, terj. Muammal hamidy(Surabaya: PT. Bina Ilmu, 2010), h.56.

${ }^{13}$ Abdul Rahman Ghazaly, Fiqh Muamalat,....h. 80-85.
} 
a) Jual beli buah-buahan yang belum tampak hasilnya.

b) Jual beli barang yang belum tampak. Contohnya menjual ikan dikolam/laut, ubi/singkong yang masih ditanam dan anak ternak yang masih dalam kandungan induknya.

3) Jual beli bersyarat adalah yang ijab qabulnya dikaitkan dengan syarat yang tidak ada kaitanya dengan jual beli atau ada unsyur merugikan yang dilarang oleh agama.

4) Jual beli yang menimbulkan kemudaratan. Segala sesuatu yang dapat menimbul kerusakan dan kemudharatan dilarang untuk diperjual belikan.

5) Jual beli yang dilarang karena dianiaya. Jual beli yang mengakibatkan penganiayaan hukumnya haram, seperti menjual anak binatang yang masih membutuhkan induknya.

6) Jual beli muhaqalah, yaitu menjual tanam-tanaman yang masih disawah atau diladang.

7) Jual beli Mukhadarah, yaitu menjual buah-buahan yang masih hijau (belum pantas dipanen).

8) Jual beli mulamasah yaitu jual beli secara sentuh-menyentuh.

9) Jual beli munabadzah, yaitu jual beli secara lempar-melempar.

10) Jual beli muzabanah, menjual buah yang basah dengan yang kering

b. Jual beli terlarang karena ada faktor lain yang merugikan pihak-pihak terkait, antara lain: 
1) Jual beli dari orang yang masih dalam tawar-menawar.

2) Jual beli dengan menghadang dagangan diluar kota/pasar.

3) Membeli barang dengan mendorong untuk ditimbun, kemudian akan dijual ketika harga naik karena kelangkaan barang tersebut.

4) Jual beli barang rampasan atau curian. ${ }^{14}$

Pakan ternak adalah bahan makanan tunggal atau campuran, baik yang diolah maupun yang tidak diolah,yang diberikan kepada hewan untuk kelangsungan hidup, berproduksi dan berkembang biak. Pakan hijauan adalah semua bahan pakan yang berasal dari tanaman ataupun tumbuhan berupa daundaunan, terkadang termasuk batang, ranting dan bunga.Kebutuhan ternak akan pakan hijauan adalah mutlak, dalam sistem produksi ternak ruminansia hijauan pakan ternak (HPT) sebagai bahan pakan sumber serat mutlak, diperlukan sepanjang tahun.Pakan hijauan yang diberikan kepada ternak, dapat dalam dua macam bentuk, yaitu hijauan segar dan hijauan kering. Namun, ketersediaan pakan hijauan, utamanya hijauan segar terkadang menjadi kendala dalam pemeliharaan ternak ruminansia.bahwa ketersediaan pakan menjadi kendala utama khususnya di negara berkembang karena suplai hijauan pakan ternak (HPT) baik dari segi kualitas maupun kuantitas selalu mengalami kelangkaan dan berfluktuasi sepanjang tahun. ${ }^{15}$

Tahu diproduksi dengan memanfaatkan sifat protein, yaitu akan menggumpal bila bereaksi dengan asam. Penggumpalan protein oleh asam cuka akan berlangsung secara cepat dan bersamaan diseluruh bagian cairan sari kedelai,

\footnotetext{
${ }^{14}$ Abdul Rahman Ghazaly, Fiqh Muamalat,... h. 85-87.

15 Jumriah Syam,Dkk,Pengaruh Pemberian Pakan Konsetrat Dan Urea Molases Blok Umb Terhadap Sapi Potong,Jurnal Ilmu Dan Industri Perternakan, 2, 3 (Juni 2016), h.1.
} 
sehingga sebagian besar air yang semula tercampur dalam sari kedelai akan terkumpul di dalamnya. Pengeluaran air yang terkumpul tersebut dapat dilakukan dengan memberikan tekanan. Semakin besar tekanan yang diberikan, semakin banyak air dapat dikeluarkan dari gumpalan protein. Gumpalan protein itulah yang disebut dengan tahu.

Ampas tahu merupakan hasil samping dalam proses pembuatan tahu berbentuk padat dan didapatkan dari bubur kedelai yang diperas. Ampas tahu masihmempunyaikandungan protein yang relatiftinggi karena pada proses pembuatan tahutidak semua kandungan protein terekstrak,lebih-lebih bila memakai prosespenggilingan sederhana dan tradisional.Meskipun demikian, ampas tahu belumbanyak dimanfaatkan secara optimal, bahkanmasih ada pengrajin tahu yang membuanglimbah atau ampas tahu begitu saja sehinggamenimbulkan pencemaran lingkungan disekitarnya. ${ }^{16}$

\section{A. Sadd Adz-Dzari'ah}

\section{Definisi Sadd Adz-Dzari'ah}

Sadd Adz-Dzari'ah dari segi bahasa terdiri dari dua kata, yaitu (سد) artinya menutup dan kata (الذريعة) berarti wasilah atau jalan ke suatu tujuan. Dengan demikian, Sadd Adz-Dzari'ah secara bahasa dapat diartikan dengan menutup jalan kepada suatu tujuan. ${ }^{17}$ Maksudnya yaitu menutup jalan yang tujuannya menuju kepada kerusakan. Sesuai dengan tujuan

\footnotetext{
${ }^{16}$ Lucia Hermawati Rahayu, dkk, Teknologi Pembuatan Tepung Ampas Tahu Untuk Produksi Aneka Makanan Bagi Ibu-Ibu Rumah Tangga Di Kelurahan Gunungpati, Juornal Pengapdian Kepada Masyarakat. 7, 1,( Semarang, 2016), h. 69.

${ }^{17}$ Satria Efendi, Ushul Fiqh, (Jakarta: Prenada Media, 2005), h. 172
} 
syara'menetapkan hukum untuk para Mukallaf, agar mencapai kemaslahatan dan menjauhkan diri dari kerusakan. ${ }^{18}$

Definisi lain terhadap Sadd Adz-Dzari'ah yaitu "apa yang menyampaikan kepada sesuatu yang terlarang mengandung kerusakan”

Untuk menempatkan dalam bahasa sesuai yang dituju, kata Dzari'ah itu di dahului dengan kata sadd yang artinya "menutup" maksudnya adalah menutup jalan terjadinya kerusakan. ${ }^{19}$

Dalam pembahasan hukum taklifi tentang "wajib" telah diuraikan tentang hukum melakukan segala sesuatu yang membawa kepada dan mendahului suatu perbuatan wajib, yang disebut "muqaddimah wajib". Ialah wasilah (perantara) kepada suatu perbuatan yang dikenai hukum, maka ia disebut Dzari'ah. Oleh kare itu para penulis dan ulama ushul memasukan pembahasan tentang muqaddimah wajib kedalam pembahasan Sadd Adz-Dzari'ah karena sama-sama sebagai perantara kepada sesuatu. ${ }^{20}$

Perbedaan antara muqaddimah wajib dengan Sadd Adz-Dzari'ah yang terletak pada ketergantungan perbuatan pokok yang dituju kepada perantara atau wasilah. Sedangkan Sadd Adz-Dzari'ah hukum perbuatan pokok tidak tergantung pada perantara atau wasilah. Perbedaan diantara muqaddimah wajib dan Sadd Adz-Dzari'ahakan lebih tepat jika dilihat dari segi bentuk perbuatan pokok yang berada dibalik perantara tersebut. Bila

\footnotetext{
${ }^{18}$ Masykur Anhari, Ushul Fiqh, (Surabaya: Diantama, 2008), h. 116.

${ }^{19}$ Amir Syarifuddin, Ushul Fiqh Jilid 2, ...h. 424.

${ }^{20} \mathrm{Ibid}$.
} 
perbuatan pokok yang dituju merupakan perbuatan yang disuruh, maka wasilah-nya disebut muqaddimah. Sedangkan bila perbuatan pokok yang dituju adalah perbuatan yang dilarang, maka wasilah-nya adalah Dzari'ah. ${ }^{21}$

Amir syarifuddin mengutip dari Wahbah Az-Zuhaili membagi Dzari'ah menjadi empat kategori. Pembagian ini mempunyai signifikasi manakala dihubungkan dengan kemungkinan membawa dampak negatif (mafsadah) dan membantu tindakan yang telah dilarang. Adapun pembagian itu sebagai berikut:

a. Dzari'ah yang secara pasti dan meyakinkan akan membawa kepada mafsadah. Terhadap Dzari'ah yang semacam ini, para ahli ushulfiqh sepakat untuk mengharamkannya. Contohnya adalah menggali sumur saat malam hari saat pemilik rumah tidak mengetahuinya, perbuatan ini dilaang karena jika pemilik rumah tidak mengetahuinya, perbuatan ini dilarang karena jika pemilik rumah jatuh ke dalam sumur maka penggali sumur tersebut yang akan di hukum.

b. Dzari'ah yang berdasarkan dugaan kuat akan membawa kepada mafsadah. Misalnya, menjual buah anggur kepada orang atau perusahaan yang biasa memproduksi minuman keras, Terhadap Dzari'ah semacam ini, ulama ushul fiqh telah bersepakat menetapkan keharamannya.

\footnotetext{
${ }^{21}$ Ibid. h. 425.
} 
c. Dzari'ah yang kecil atau jarang kemungkinannya membawa kepada mafsadah, seperti menanam dan membudidayakan buahanggur. Terhadap Dzari'ah semacamini, ulama ushulfiqh bersepakat menetapkan kebolehannya.

d. Dzari'ah yang berdasarkan asumsi biasa (bukan dugaankuat) akan membawa mafsadah. Misalnya, transaksi jualbeli secara kredit. Berdasarkan asumsi biasa, transaksi demikian akan membawa kearah mafsadah terutama bagi debitur. Mengenai Dzari'ah semacamini, ulama ushulfiqh berbeda pendapat. ${ }^{22}$

e. Sebagian menyatakan bahwa perbuatan tersebut dilarang atas dasar Sadd Adz-Dzari'ah dan sebagian yang lain berpendapat sebaliknya.Terlepas dari kategori mana Dzari'ah yang harus dilarang atau diharamkan, yang jelas Sadd Adz-Dzari'ah dapat dipahami memelihara kemaslahatan dan menghindari kemafsadatan. ${ }^{23}$

\section{Dasar Hukum Sadd Adz-Dzari'ah}

Pendapat ini dikemukakan oleh kalangan Malikiyah dan Hanabilah.Mereka melandasi ini dengan argumentasi dari Alquran dan hadis.Pada dasarnya, tidak ada dalil yang jelas dan pasti baik menurut nas maupun ijma' ulama tentang boleh atau tidaknya mengunakan Sadd AdzDzari'ah. Namun demikian, ada beberapa nas yang mengarah kepadanya, baik Al-quran maupun As-Sunnah di antaranya yaitu:

${ }^{22}$ Satria Efendi, Ushul Fiqh ,...h. 174.

${ }^{23}$ Asnawi, Perbandingan Ushul Fiqh, (Jakarta: Amzah, 2013),h. 143. 
a. Alquran

1. Surah Al-An'am ayat 108

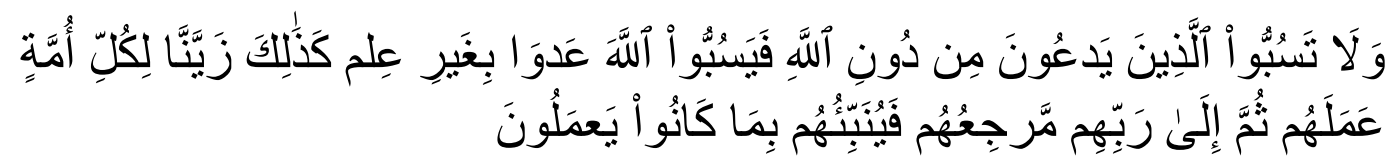

Artinya: "Dan janganlah kamu memaki sesembahan yang mereka sembah selain Allah, karena mereka nanti akan memaki Allah dengan melampaui batas tanpa dasar pengetahuan. Demikianlah, Kami jadikan setiap umat menganggap baik pekerjaan mereka. Kemudian kepada Tuhan tempat kembali mereka, lalu Dia akan memberitahukan kepada mereka apa yang telah mereka kerjakan." 4

Pada ayat di atas, mencaci maki tuhan atau sembahan agama lain adalah Sadd Adz-Dzari'ah yang akan menimbulkan sesuatu mafsadah yang dilarang, yutu mencaci maki Tuhan. Sesuai dengan teori psikologi mechanism defense, orang yang Tuhannya dicaci kemungkinan akan membalas mencaci Tuhan yang diyakini oleh orang sebelumnya mencaci. Karena itulah, sebelum balasan caci maki itu terjadi, maka larangan mencaci maki tuhan agama lain merupakan tindakan preventif. Mencaci berhala tidak dilarang Allah SWT, tetapi ayat ini pelarang kaum muslimin mencaci dan menghina berhala, karena larangan ini dapat menutup pintu kearah tindakan orang-orang musyrik mencaci dan memaki Allah Swt secara melampui batas. ${ }^{25}$

2. Surah An-Nur ayat 31 141.

${ }^{24}$ Departemen Agama, Al-Qur'an dan Terjemahnya, (Bandung: CV. Diponegoro, 2005), h.

${ }^{25}$ Ahmad Sanusi Dan Sohari, Ushul Fiqh, (Bandung: Gema Risalah Press, 1993), h. 91. 


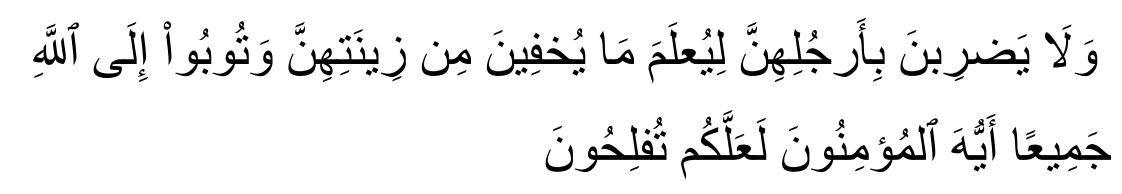

Artinya: "Dan janganlah mereka menghentakkan kakinya agar diketahui perhiasan yang mereka sembunyikan. Dan bertobatlah kaтu seтиa kepada Allah, wahai orang-orang yang beriman, agar kamu beruntung." 26

Wanita menghentakkan kakinya sehingga terdengar gemerincing gelang kakinya, tetapi perbuatan itu akan menarik hati laki-laki lain untuk mengajaknya berbuat zina, maka perbuatan itu dilarang sebagai usaha untuk menutup pintu yang menuju ke arah perbuatan zina. ${ }^{27}$

Diantara kaidah fiqih yang bisa dijadikan dasar penggunaan Sadd AdzDzari'ah adalah:

$$
\text { جَلْبُ المصنَا لِحِح وَ دَرْهُ المفَا سِدِ }
$$
Artinya: meraih kemaslahatan dan menolak kemafsadatan. ${ }^{28}$

Maksud dari kaidah fiqih di atas adalah bahwa jika terjadi pertentangan antara kemaslahatan (kebaikan) dan kemudharatan pada suatu perbuatan maka lebih diutamakan menarik kemaslahatan. Hal ini disebabkan karena perintah meninggalkan larangan tebih kuat dari pada perintah menjalankan kebaikan

Para ulama membagi Sadd Adz-Dzari'ah menjadi dua segi, segi kualitas kemafsadatan dan segi kemafsadatan yang ditimbulkan. Pembagiannya adalah sebagai berikut: 353.

${ }^{26}$ Departemen Agama, Al-Qur'an dan Terjemahnya, (Bandung: CV. Diponegoro,2005), h.

${ }^{27}$ Ahmad Sanusi Dan Sohari, Ushul Fiqh,...h. 91.

${ }^{28}$ Djazuli, Kaidah-Kaidah Fiqih: Kaidah-Kaidah Hukum Islam dalam Menyelesaikan Masalah-Masalah yang Praktis, (Jakarta: Kencana, 2006). h. 173. 
1 Dari segi kualitas kemafsadatan

a. Perbuatan yang dilakukan itu membawa kepada kemafsadatan secara pasti.

b. Perbuatan yang boleh dilakukan karena jarang membawa kemafsadatan.

c. Perkara yang dilakukan biasanya atau kemungkinan besar membawa kearah kemafsadatan.

d. Perbuatan itu pada dasarnya boleh dilakukan.

2 Dari segi kemafsadatan yang ditimbulkan

a. Perbuatan itu membawa kepada mafsadah

b. Perbuatan itu pada dasarnya perbuatan yang boleh dilakukan atau dianjurkan tetapi dijadikan jalan melakukan suatu perbuatan yang haram. ${ }^{29}$

Sedangkan menurut Ibnu al-Qoyyim Sadd Adz-Dzari'ah bila ditinjau dari akibat (dampak) yang ditimbulkannya terbagi menjadi empat macam, yaitu:

1) Dzari'ah yang memang pada dasarnya membawa kepada kerusakan seperti meminum minuman keras yang membawa pada kerusakan akal, atau zina yang akan membawa pada kerusakan keturunan.

2) Dzari'ah yang awalnya untuk sesuatu yang mubah, namun akhirnya menuju pada perbuatan buruk yang merusak, seperti

\footnotetext{
${ }^{29}$ Rachmat Syafi' i, Ilmu Ushul Fiqh,(Bandung: CV. Pustaka Setia, 2018), h. 136.
} 
nikah muhalil atau mencaci sesembahan agama lain. Nikah itu sendiri sebenarnya boleh, tetapi karena tujuannya semata agar menghalalkan yang haram, maka menjadi terlarang.

3) Dzari'ah yang semula untuk sesuatu yang mubah. Seperti berhias bagi wanita yang menjalani iddah ditinggal mati suaminya. Berhias itu pada dasarnya boleh, tapi berhiasnya wanita iddah seperti itu keadaanya menjadi lain.

4) Dzari'ah yang semula untuk sesuatu yang mubah, namun keburukannya lebih kecil daripada kebaikannya. Contohnya seperti melihat wajah wanita pada saat meminang/khitbah. ${ }^{30}$

Dalam menentukan hukum melalui jalan atau sarana yang mengharamkan kepada suatu tujuan, perlu di perhatikan:

a. Tujuan.jika tujuanya dilarang, maka jalanyapun dilarang dan jika tujuanya wajib, maka jalanyapun diwajibkan.

b. Niat.jika niatnya untuk mencapai suatu yang halal, maka hukum sarananya halal,dan jika niat yang ingin dicapai haram, maka sarananyapun haram.

c. Akibat dari suatu perbuatan. Jika akibat dari suatu perbuatan menghasilkan kemaslahatan seperti yang diajarkan syari'ah, maka wasilah hukumnya boleh dikerjakan, dan sebaliknya jika akibat

${ }^{30}$ Ali Imron, Menerapkan Hukum Islam Yang Inovatif Dengan Menerapkan Metode Sadd AdzDzari'ah Jurnal Ilmiah Ilmu Hukum QISTI,(Semarang,2010), h. 85. 
perbuatan adalah kerusakan walaupun tujuanya demi kebaikan maka hukumnya tidak boleh.

Dalam hal ini dasar pemikiran para ulama adalah bahwa setiap perbuatan mengandung dua sisi yaitu sisi yang mendorong untuk berbuat dan sasaran tujuan yang menjadi natijah (kesimpulan/akibat) dari perbuatan itu, menurut natijahnya, perbuatan itu ada 2 bentuk:

a. Natijahnya baik, maka segala sesuatu yang mengarah kepadanya adalah baik dan di anjurkan untuk mengerjakanya.

b. Natijahnya buruk, maka segala sesuatu yang mengarah kepadanya adalah buruk dan karenanya dilarang untuk mengerjakanya. ${ }^{31}$

Dalam hal ini ada beberapa pendapat ulama tentang kehujjahan atau kedudukan Sadd Adz-Dzari'ah yaitu sebagai berikut:

a. Imam Malik dan Imam Ahmad Ibnu Hambal dikenal sebagai dua orang Imam yang memakai Sadd Adz-Dzari'ah. Oleh karena itu, kedua imam ini menganggap bahwa Sadd Adz-Dzari'ah dapat menjadi hujjah. Khususnya Imam Malik yang dikenal selalu mempergunakannya di dalam menetapkan hukum syara'. Imam Malik di dalam mempergunakan Sadd Adz-Dzari'ah sama dengan mempergunakan maslahah mursalah dan uruf wal adah. ${ }^{32}$

b. Imam Ibnu Qayyim mengatakan, bahwa penggunaan Sadd AdzDzari'ah merupakan satu hal yang penting sebab mencakup $1 / 4$ dari

\footnotetext{
${ }^{31}$ Muaidi, Saddu Al-Dzari'ah Dalam Hukum Islam,Tafaquh, Jurnal Hukum Ekonomi Syaria'h Dan Ahwal Syahsiyah, (Lombok Tengah,2016), h.39.

${ }^{32}$ Amir Syarifuddin, Ushul Fiqh Jilid 2, ...h. 434.
} 
urusan agama, dan dalam Sadd Adz-Dzari'ah termasuk perintah (Amar) dan larangan (Nahi). ${ }^{33}$

c. Ulama Hanafi dan Syafi'i menerima Sadd Adz-Dzari'ah sebagai dalil dalam masalah-masalah tertentu dan menolaknya dalam kasus-kasus lain. Imam Syafi'i, membolehkan seseorang karena udzur, seperti sakit dan musafir,

d. untuk meninggalkan salat Jumat dan menggantinya dengan salat zuhur. Akan tetapi, menurutnya ia secara tersembunyi dan diam-diam mengerjakan salat zuhur tersebut, agar tidak dituduh sengaja meninggalkan salat Jum'at. ${ }^{34}$

e. Ulama Zahiriyyah tidak mengakui kehujjahan Sadd Adz-Dzari'ah sebagai salah setu dalil dalam menetapkan bukum syara'. Hal tersebut sesuai dengan prinsip mereka yang hanya menggunakan nash (Alquran dan as-Sunnah) dan tidak menerima campur tangan logika (ra'yu) dalam masalah hukum. Pada umumnya semua ulama menerima metode Sadd Adz-Dzari'ah kecuali ulama zahiriyyah. Hanya saja penerapannya yang berbeda, perbedaan tentang seberapa ukuran kualifikasi Sadd Adz-Dzari'ah yang akan menimbulkan kerusakan dan yang dilarang.

Berdasarkan pendapat ualama di atas tentang kehujjahan Sadd AdzDzari'ah dapat disimpulkan bahwa menggunakan Sadd Adz-Dzari'ah

\footnotetext{
${ }^{33} \mathrm{Ibid}$.

${ }^{34}$ Rachmat Syafe'i, Ilmu Ushul Fiqh,(Bandung:Pustaka Setia, 2015), h. 139.
} 
dalam nenetapkan sebuah hukum sama dengan menggunakan maslahah mursalah dan uruf wal adah yang mencakup 1/4 dari urusan agama, Pada umumnya semua ulama menerima metode Sadd Adz-Dzari'ah kecuali ulama zahiriyyah. Hanya saja penerapannya yang berbeda, perbedaan tentang seberapa ukuran kualifikasi Sadd Adz-Dzari'ah yang akan menimbulkan kerusakan dan yang dilarang. ${ }^{35}$

\section{Kesimpulan}

Pelaksanaan jual beli ampas tahu yang terjadi di pabrik tahu desa Telaga Meuku Dua dalam prakteknya pemilik pabrik tahu menjual ampas tahunya kepada masyarakat setempat yang memiliki ternak sapi dan ternak kambing, serta kepada peternak babi yang datang dari luar daerah untuk membeli ampas tahu. Dalam prakteknya sipembeli yang datang langsung ke pabrik untuk membeli dan membawa ampas tahu yang sudah di pesan sebelumnya walaupun yang datang dari luar daerah merekalah yang mengambil langsung ke pabrik tahu dan sistem pebayaranya biasanya di lakukan secara tunai di pabrik tahu Telaga Meuku Dua.

Jual beli ampas tahu untuk pakan ternak babi di pabrik tahu desa Telaga Meuku Dua termasuk kategori jual beli yang dilarang. Dikarenakan dalam pemanfaatan ampas tahunya dijadikan sebagai pakan ternak babi. Agama Islam telah secara tegas melarang untuk memanfaatkan daging babi. Dengan demikian dalam hukum Islam

\footnotetext{
${ }^{35}$ Ibid.
} 
perbuatan jual beli ampas tahu untuk pakan ternak babi juga dilarang karena termasuk Sadd adz-Dzari'ah yang menutup jalan terjadinya kemafsadatan dalam jual beli ampas tahu untuk pakan ternak babi tergolong persangkaan yang kuat yang menyebabkan terjadinya hal-hal yang rusak dan dilarang. Jual beli ampas tahu untuk pakan ternak babi

\section{DAFTAR PUSTAKA}

Abdul Wahab Khallaf, Kaidah-Kaidah Hukum Islam(Ilmu Ushulul Fiqh), Ter: Noer Iskandar

Al-Barsany dan Moh. Tolehah Mansoer, (Jakarta : CV. Rajawali Pers, 1993), h. 64.

Ahmad Sanusi Dan Sohari, Ushul Fiqh, (Bandung: Gema Risalah Press, 1993), h. 91.

Al-Hafiz ibnu hazar al-'asqalani, terjemahan lengkap Bulughul Maram kumpuln hadis tentang hukum dan adab,(surakarta:Ziyad Books, 2017),h.274.

Ali Imron, Menerapkan Hukum Islam Yang Inovatif Dengan Menerapkan Metode Sadd Adz-Dzari'ah Jurnal Ilmiah Ilmu Hukum QISTI,(Semarang,2010), h. 85.

Asnawi, Perbandingan Ushul Fiqh, (Jakarta: Amzah, 2013),h. 143.

Asy-Syaukani, Al Imam Muhammad Bin Ali Bin Muhammad, Tafsir Fathul Qadir, Terj. Amir Hamjah Fachruddin, (Jakarta: Pustaka Azam, 2009), h.184.

Burhan Bungin, Metodologi Penelitian Sosial: Fromat 2 Kuantitatif dan

Kualitatif, (Surabaya: Airlangga University Press, 2005), h. 128.

Burhan Bungin, penelitian kualitatif : komunikasi, Ekonomi, kebijakan publik dan ilmu sosial lainnya,(Jakarta: Kencana, 2009), h. 115.

Departemen Agama, Al-Qur'an dan Terjemahnya, (Bandung: CV. Diponegoro, 2005), h.. 47.

Djazuli, Kaidah-Kaidah Fiqih: Kaidah-Kaidah Hukum Islam dalam Menyelesaikan Masalah-Masalah yang Praktis, (Jakarta: Kencana, 2006). h. 173.

Harun, Fiqh Muamalah, (Surakarta: Muhammadiyah University Press, 2017), h. 66. 
Hendi Suhendi, Fiqh Muamalah, (Jakarta: Rajawali Pers, 2014), h. 68.

Imam mustofa, Fiqih Muamalat Kontemporer, (Jakarta: PT Raja Grafindo Persada, 2016), h. 22

Jumriah Syam,Dkk,Pengaruh Pemberian Pakan Konsetrat Dan Urea Molases Blok Umb Terhadap Sapi Potong,Jurnal Ilmu Dan Industri Perternakan, 2, 3 (Juni 2016), h.1

Lexy J. Moelong, Metodologi Penelitian Kualitatif, (Bandung: PT. Remaja Rosdakaya, 2008), h. 4

Lucia Hermawati Rahayu, dkk, Teknologi Pembuatan Tepung Ampas Tahu Untuk Produksi Aneka Makanan Bagi Ibu-Ibu Rumah Tangga Di Kelurahan Gunungpati, Juornal Pengapdian Kepada Masyarakat. 7, 1,( Semarang, 2016), h. 69.

Mardani, Hukum Ekonomi Syariah, (Jakarta : PT Refika Aditama,2011), h. 179.

Masykur Anhari, Ushul Fiqh, (Surabaya: Diantama, 2008), h. 116

Muaidi, Saddu Al-Dzari'ah Dalam Hukum Islam,Tafaquh, Jurnal Hukum Ekonomi Syaria'h Dan Ahwal Syahsiyah, (Lombok Tengah,2016), h.39.

Muhammad Daud Ali, Asas-asas Hukum Islam, (Jakarta : Rajawali Press, 2007), h. 144.

Muhammad Nashruddin al Albani, Shahih sunan ibnu Majah, Ter: Ahmad Taufik Abdurrahman, Jilid 2 (Jakarta: Pustaka Azzam ,2007) h.313.

Mukti Fajar, Yulianto Achmad, Dualisme Penelitian Hukum Normatif dan Empiris,

Nasrun Haroen, Fiqh Muamalah, ....h.119

Nasrun Haroen, Fiqh Muamalah, Jakarta:Gaya Media Pratama,2000), h. 115.

Rachmat Syafe'i, Ilmu Ushul Fiqh,(Bandung:Pustaka Setia, 2015), h. 139.

Riduawan,Metode \& Teknik Penyusunan Tesis.(Bandung: Alfabeta, 2006), h. 105

Satria Efendi, Ushul Fiqh, (Jakarta: Prenada Media, 2005), h. 172

Sayyid sabiq, Fiqih Sunnah, Jilid 5,... h. 37-38.

Soerjono Soekanto \& Sri Mamudji, Penelitian Hukum Normative Suatu Tinjauan Singkat, (Jakarta: Raja Grfindo Persada, 1985), h. 1 
Sulaiman Rasyid, Fiqih Islam, (Jakarta: Attahiriyah, 1954), h. 270.

Syaikh Abdurahman Bin Nasir As-Sa'di, Tafsir Al-Karim Ar-Rahman Fi Tafsir Kalam Al-Mannan, Terj. Muhammad Iqbal, Dkk, (Jakarta: Darul Haq, 2005), h.64. 
sama halnya seperti jual anggur untuk di buatkan khamar, karena haramnya khamar sama seperti haramnya babi maka oleh sebab itu hukumnya sama-sama dilarang. Sekalipun pemanfaatan daging babi digunakan bagi non-Muslim hukumnya juga dilarang karena pendapat mazhab Syafi'i bahwasanya non-Muslim juga dikenakan hukum taklif sama halnya seperti umat Muslim . 
sama halnya seperti jual anggur untuk di buatkan khamar, karena haramnya khamar sama seperti haramnya babi maka oleh sebab itu hukumnya sama-sama dilarang. Sekalipun pemanfaatan daging babi digunakan bagi non-Muslim hukumnya juga dilarang karena pendapat mazhab Syafi'i bahwasanya non-Muslim juga dikenakan hukum taklif sama halnya seperti umat Muslim . 